\title{
Structural characteristics of wet montane forests in east-central British Columbia
}

\author{
by S. C. DeLong ${ }^{1}$, J. M. Arocena ${ }^{2}$, and H. B. Massicotte ${ }^{2}$
}

\begin{abstract}
Structural characteristics of forest stands were examined along a post-fire age chronosequence for wet montane sub-boreal and subalpine forests in the northern portion of the Rocky Mountains in British Columbia, Canada. The objective was to develop criteria that could be used to assess the extent to which managed stands approximate the structural characteristics of natural stands. Twelve and fifteen stands were sampled in wet montane sub-boreal and high-elevation subalpine forests, respectively. Tree density, variation in tree size, snag density by size class and coarse woody debris volume were examined for young (0-70 years), mature (71-140 years), and old (> 140 years) stands. Apart from a general increase in average tree size and a decrease in snag density, changes in other stand attributes over time since disturbance were limited, especially when compared to forests in drier climates at similar latitudes. The combination of low density and large variability in tree size of the young wet montane sub-boreal stands appear to be unusual for low elevation forests that originate from stand-replacing wildfire. In the study area, current management practices of salvage-logging firekilled stands and planting relatively high densities of spruce on harvested sites should be examined in light of our data. This study illustrates the importance of developing area-specific ecosystem management guidelines relating to stand structure.
\end{abstract}

Key words: stand structure, woody debris, snags, Picea engelmannii, Abies lasiocarpa, wildlife habitat

\begin{abstract}
Les caractéristiques structurelles des peuplements forestiers ont été examinées au sein d'une chronoséquence reposant sur l'âge des forêts montagneuses humides sub-boréales et subalpine issues d'incendie de la portion nord des Montagnes Rocheuses de la Colombie-Britannique au Canada. L'objectif était d'élaborer des critères qui pourraient être utilisés pour évaluer jusqu'à quel point les peuplements aménagés reproduisent les caractéristiques structurelles des peuplements naturels. Douze et quinze peuplements ont été échantillonnés respectivement dans des forêts montagneuses humides sub-boréales et subalpines de haute altitude. La densité des arbres, la variation de la taille des arbres, la densité des chicots par classe de taille et le volume des gros débris ligneux ont été examinés pour des peuplements jeunes (0-70 ans), mûrs (71 à 140 ans) et âgés (> 140 ans). Mis à part un accroissement généralisé de la taille moyenne des arbres et une diminution de la densité des chicots, les changements dans les autres caractéristiques des peuplements au cours du temps depuis la perturbation étaient peu nombreux, surtout par comparaison avec les forêts des climats plus secs d'altitude semblable. La combinaison de densité faible et de grande variabilité de la taille des arbres dans les peuplements jeunes sub-boréaux de montagne semble être inhabituelle dans le cas des forêts de faible altitude qui sont issues d'incendie de forêts non contrôlés régénérateurs. Dans la zone d'étude, les pratiques actuelles d'aménagement de récupération du bois provenant des forêts incendiées et la plantation à densité relativement élevée d'épinette sur les sites récoltés devraient être examinées à la lumière de nos données. Cette étude démontre l'importance de l'élaboration de directives d'aménagement écosystémique spécifiques à une zone donnée reposant sur la structure du peuplement.
\end{abstract}

Mots-clés : structure du peuplement, débris ligneux, chicots, Picea engelmannii, Abies lasiocarpa, habitat faunique

\section{Introduction}

Public criticism of past practices and a better understanding of natural systems has suggested that forest harvesting should be designed to achieve the landscape patterns and habitat conditions that are maintained by natural disturbance regimes (Franklin 1989, Hansen et al. 1991, Bergeron and Harvey 1997). This suggestion is derived in part from evidence that disturbance has a key eco-

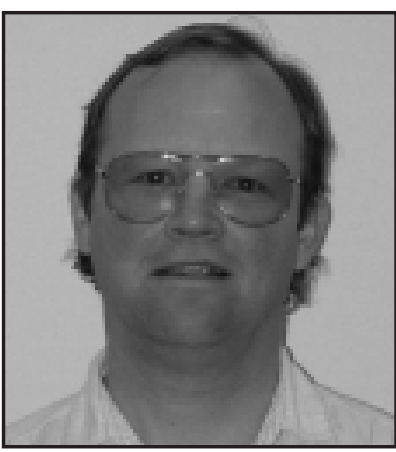

S. C. Delong

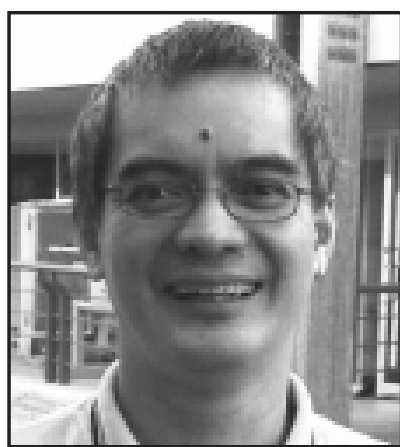

J. M. Arocena

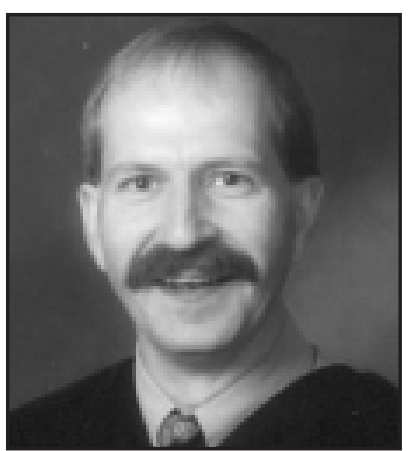

H. B. Massicotte logical role in many forested ecosystems (Zackrisson 1977, Van Wagner 1978, Hessburg et al. 1994). The underlying assumption is that the biota of a forest are adapted to the range of conditions created by natural disturbances and thus should be less

${ }^{1}$ Ministry of Forests, $10114^{\text {th }}$ Ave., Prince George, B.C. V2L 3H9. E-mail: Craig.Delong@gems1.gov.bc.ca

${ }^{2}$ University of Northern British Columbia, Forestry Program, College of Science and Management, 3333 University Way, Prince George, B.C. V2N 4Z9.

E-mail: arocenaj@unbc.ca; hugues@unbc.ca impacted by timber harvest if the resulting patterns resemble those of natural disturbances (Hunter 1993, Swanson et al. 1993, Bunnell 1995).

Tree species composition and vertical and horizontal structure within individual stands affects the diversity and abundance of animal and plant species (Willson 1974, Alaback 1982, Carey et al. 1999). Biological legacies of natural disturbance such as old large-diameter trees, snags and woody debris play a fundamental role in maintaining the long-term ecological functioning of an ecosystem (Hansen et al. 1991, Amaranthus 1994). The 
role of large trees, snags and logs as important habitat for many groups of organisms has been well documented (Mannan et al. 1980, Harmon et al. 1986, Harmon and Franklin 1989, Lesica et al. 1991, Bader et al. 1995, Dupuis et al. 1995, Hutto 1995, Kaila et al. 1997).

The impacts of forest management appear to exceed and confound those of natural disturbance agents (Swanson et al. 1993, DeLong and Tanner 1996). Hence, understanding how forest landscape and stand elements are affected by natural disturbance is useful for developing alternative management systems that more closely approximate these effects. In addition, examining natural stand development relative to predicted development of stands managed to meet timber production goals can highlight differences of potential ecological consequence.

Recent studies have examined pattern and process in natural forests of central British Columbia. However, most of the work has been restricted to sub-boreal forests occurring in moist climates where stands are initially dominated by lodgepole pine (Pinus contorta Dougl. ex Loud.) (Kneeshaw 1992, Clark 1994, Andison 1996, DeLong and Tanner 1996, Clark et al. 1998). Although some data exist on disturbance rate and patch size for wet montane climates (Hawkes et al. 1997, DeLong 1998), little stand-level information is available and is restricted to older ( $>140$ years) natural stands and younger ( $<40$ years) managed stands. We intended to fill this gap by examining key stand structural attributes over an age sequence following fire within the wet montane forest of the northern Rocky Mountains near Prince George, British Columbia.

In this paper, we present information about the distribution of standing trees and volume of downed wood across age sequence for wet sub-boreal and subalpine stands of fire origin. We interpret the data relative to natural stand development in drier sub-boreal climates and managed stand development under current forest practices. We then discuss potential ecological consequences of obvious differences between natural and managed stand development. This information should provide guidance to managers for emulating natural stand structure within wet montane climates similar to that investigated.

\section{Methods and Data Analysis \\ Study area}

The study was conducted in a portion of the Misinchinka Ranges of the Rocky Mountains near Prince George extending from about $53.5-55^{\circ} \mathrm{N}$ and $120-122.5^{\circ} \mathrm{W}$. Sampling was conducted within three different biogeoclimatic units: the very wet Subboreal Spruce (SBSvk), the Misinchinka variant of the wet cool Engelmann Spruce Subalpine fir (ESSFwk2), and the Cariboo variant of the wet cold Engelmann Spruce Subalpine fir (ESSFwc3) (DeLong 1996, DeLong et al. 1994). The SBSvk has an elevation range of 615-1050 m, mean annual precipitation (MAP) of $1250 \mathrm{~mm}$, and mean annual temperature (MAT) of $2.6^{\circ} \mathrm{C}$ (DeLong 1996). The ESSFwk2 has an elevation range of 1000-1300 m, MAP of $1538 \mathrm{~mm}$ and MAT of $0.3^{\circ} \mathrm{C}$ while the ESSFwc3 has an elevation range of 1300-1700 m, MAP of 1408 $\mathrm{mm}$ and MAT of $-1.0^{\circ} \mathrm{C}$ (DeLong et al. 1994). The forest stands are generally dominated by hybrid white spruce (Picea glauca (Moench) Voss $\times$ engelmannii Parry ex Engelm.) or subalpine fir (Abies lasiocarpa (Hook.) Nutt.) at low elevations $(<1100 \mathrm{~m})$ and Engelmann spruce (Picea engelmannii Parry ex Engelm.) and subalpine fir at higher elevations. Small localized upland areas at lower elevations may be dominated by Douglas-fir (Pseudotsuga menziesii (Mirb.) Franco), western hemlock (Tsuga heterophylla (Raf.) Sarg.), paper birch (Betula papyrifera Marsh.), or trembling aspen (Populus tremuloides Michx.). Black cottonwood (Populus trichocarpa Torr. \& A. Gray) is common along larger watercourses and black spruce (Picea mariana (P. Mill.) B.S.P.) or lodgepole pine dominate wetlands.

Bedrock consists predominantly of sedimentary and metamorphic rocks of the Precambrian Miette Group, along with Cambrian Gog quartzite and Silurian limestones. The predominant soils are Dystric Brunisols and Humo-Ferric Podzols developed on till or sandy glaciofluvial materials and Gray Luvisols developed on glaciolacustrine terraces or till (DeLong 1996).

\section{Sampling design}

We used quadrat plot sampling to compare various ecological attributes between stands that varied in age since disturbance. We used maps of estimated stand age developed from British Columbia Ministry of Forests (BCMF 1992) forest inventory to locate potential sample sites. For the inventory, forest age of a map polygon is interpreted from 1:15840 black and white aerial photographs by comparing height, crown closure and crown condition with adjacent polygons. Periodic groundtruthing is performed to verify stratification and standards require polygon age to be within $15 \%$ of actual age (BCMF 1992). For most $<70$-year-old stands, the actual year of the fire was known from fire history records maintained by the British Columbia Ministry of Forests (BCMF). To minimize betweensite variation, we selected sites that were: a) slightly drier than mesic to slightly wetter than mesic in moisture regime; b) represented the Sx - Devils's club (SBSvk1/01) (DeLong 1996), the Bl - Oakfern - Knight's plume (ESSFwk2/01) or B1 Rhododendron - Oakfern (ESSFwc3/01) (DeLong et al. 1994) site series; c) located in areas with no evidence of prior tree cutting; and d) at least one tree length (approximately 20-30 m) from obvious clearings, stands of another age, or stands not meeting these criteria. Since Engelmann spruce and subalpine fir are not resistant to fire there is little live remnant structure left after fire. We were careful to examine the largest trees in the plot to reduce the uncertainty of whether they had survived the previous fire. We examined the tree boles closely for evidence of fire scars and cored any trees that were suspect to check for buried scars. We found no evidence of trees that had survived the fire of origin in our plots.

Once a suitable stand was located, we established a 30-m by 30-m plot "subjectively without preconceived bias" as outlined by Mueller-Dombois and Ellenberg (1974). This plot size has been used in previous studies of sub-boreal stand structure and seems to provide a good compromise between sampling efficiency and capturing within stand variability. We established 12 plots in the sub-boreal (SBSvk) and 15 plots in the subalpine (ESSFwk2 and wc3). The ESSFwk2 and ESSFwc3 were treated as one sampling area that represents subalpine forests for the study area. Stands within the sub-boreal and subalpine sampling areas were equally divided among three different age classes: young (0-70 years), mature (71-140 years), and old ( $>140$ years). Due to limited number of younger $(<140$ years $)$ fire-origin stands, this represented a fairly complete sample of potential stands (18 of 28). Sampling occurred in the sub-boreal forests between 17 July and 2 August 1995, and within the subalpine forests between 29 July and 9 August 1996. 


\section{Overstory stand structure}

For all live and dead standing trees $\geq 7.5 \mathrm{~cm}$ dbh within each plot, we recorded species, diameter $(\mathrm{cm})$ at breast height $(1.3 \mathrm{~m})$, height class (veteran, main canopy, or intermediate), and presence of cavities (large $(>3 \mathrm{~cm})$, small $(<3 \mathrm{~cm})$ or both). We also estimated percent cover of the tree layer ( $>$ $10 \mathrm{~m}$ in height).

We measured heights of at least three trees of each species dominating the canopy in each plot using a Criterion 400 Survey Laser (Laser Technology Inc., Englewood, Co.). We also extracted cores from these trees at $0.6 \mathrm{~m}$ above the ground level and counted the annual rings to estimate age.

Density of live trees calculated by species, and $5-\mathrm{cm}$ diameter class was used to construct histograms of density by diameter class for each plot. For each stand age class, we also calculated the density of snags in three diameter classes $(7.5-15 \mathrm{~cm}, 15-25 \mathrm{~cm},>25 \mathrm{~cm})$ related to selection of cavity nesting species for certain tree sizes (Thomas et al. 1979, Neitro et al. 1985). The proportion of trees and snags with feeding cavities was also determined. We calculated a prominence value using tree density to summarize tree size class distribution by stand age class. Prominence values are commonly used to examine differences in composition and dominance in plant communities (Mueller-Dombois and Ellenberg 1974). Prominence was calculated as follows:

$$
\operatorname{Pr}=D \times \sqrt{P}
$$

where $\operatorname{Pr}=$ prominence value, $\mathrm{D}=$ average density of stems in a size class, and $\mathrm{P}=$ percentage of plots containing trees in a size class.

In order to compare changes in stand density over time with fire-origin stands in drier regions of the sub-boreal forest, we used unpublished data from a previous study conducted in the Mossvale variant of the moist cool Sub-boreal Spruce (SBSmk1) biogeoclimatic unit (DeLong et al. 1993), a drier plateau region of the sub-boreal forest near Prince George, British Columbia. The stands in this previous study were sampled using the same criteria for moisture regime and absence of management influence as stated above. Details of the sampling methods can be found in DeLong and Kessler (2000). In order to compare managed stands regenerating in the wetter and drier climatic regions (SBSvk and SBSmk1), we extracted data from British Columbia Ministry of Forests Integrated Silviculture Information System (ISIS) database. Data for young regenerating stands (5-20 years old) on mesic sites in the SBSvk1 and SBSmk1 were used for the comparison.

Due to a lack of managed stands in the study area older than 30 years of age, we chose to use a model to predict the density of a 75-year-old managed stand for comparison with sampled 75-year-old natural stands. We used a beta version of the BCMF software called the Table Interpolation Program for Stand Yields (TIPSY) (Mitchell, K.J., S.E. Grout, R.N. Macdonald and C.A. Watmough, unpublished report). TIPSY can generate predicted density histograms for managed stands, based on initial planting density, using yield tables generated by the BCMF model, the Tree And Stand Simulator (TASS) (Mitchell 1975). TASS simulates the growth of individual trees and stands in three dimensions and is based on growth trends in fully stocked research plots growing in a relatively pest-free environment. We used 1400 trees/ha of planted white spruce and an assumed one-year regeneration delay, as these are typical for the study area. To make the model more realistic Operational Adjustment Factors (OAFs) can be set to approximate reductions due to unproductive holes and losses toward maturity due to pests. We set these at $20 \%$ and $10 \%$ respectively as they were typically used for the study area. The model generates close to potential maximum densities that could be maintained over a given time period based on the initial planting densities and the OAFs but does not include increases in density due to ingress of natural regeneration. The model produces deterministic numbers that have no error associated with them.

\section{Coarse woody debris}

We sampled coarse woody debris (CWD) along 90-m transects using a line intercept method adapted from Trowbridge et al. (1989). The first $60 \mathrm{~m}$ of the transect consisted of two edges of the 30-m $\times 30$-m-quadrat plot at right angles to one another. To complete the transect, we used a 30-m diagonal line from the plot corner, where the first $60 \mathrm{~m}$ of transect ended, through the plot centre. For each piece of woody debris $\geq 7.5 \mathrm{~cm} \mathrm{dbh}$ that intersected the tape, we recorded diameter $(\mathrm{cm})$ at the point of intersection, decay class (Table 1), and plant root abundance class (\% of cross sectional area) as no roots, 1-24, 25-49, 50-74, $75-100$, or fine roots only.

We then estimated CWD volume by decay class for each plot using the equation described in Van Wagner $(1968,1982)$ :

$$
V=\frac{\pi^{2} \sum d^{2}}{8 L}
$$

where $\mathrm{V}$ is volume in $\mathrm{m}^{3} / \mathrm{ha}$, $\mathrm{d}$ is diameter of each piece of woody debris in $\mathrm{cm}$, and $\mathrm{L}$ is the length of the transect in meters. We generated summary statistics for volume by decay class.

\section{Analysis}

We tested for significant differences among the three age classes for each quantitative variable collected using Analysis of Variance (ANOVA). We tested each variable used in the ANOVA for homogeneity of variance using the Fmax test (Sokal and Rohlf 1969). ANOVA residuals were plotted against expected values for a normal distribution to assess normality (Wilkinson et al. 1996). These plots were compared to those of 10 random variables plotted against expected values for a normal distribution. Due to the small sample size and large range in values for most variables within each age class, few statistical differences were found. If no statistics are reported, it can be assumed that there was no difference found or the assumptions of homogeneity of variance or normality were violated. All reported ANOVA results met the assumptions of homogeneity of variance and normality. We used SYSTAT Version 6.0 (Systat Inc. Evaston, Ill.) to conduct all statistical procedures.

\section{Results \\ Live tree attributes}

Both the sub-boreal and subalpine forests exhibited the slow establishment of trees. No $<30$-year-old fire-origin stand had post-fire-origin stems $>7.5 \mathrm{~cm} \mathrm{dbh}$. Some of the $>30$-yearold young stands were better developed. Density (stems $>7.5 \mathrm{~cm}$ dbh) of a 46-year-old sub-boreal stand and a 57-year-old subalpine stand were 633 and 1267 stems/ha, respectively. The subalpine stand was located at the eastern edge of the study area in the lee of the Rocky Mountains near the boundary of drier 


\begin{tabular}{|c|c|c|c|c|c|}
\hline \multirow[b]{2}{*}{ Characteristic } & \multicolumn{5}{|c|}{ Decay classes } \\
\hline & I & II & III & IV & $\mathrm{V}$ \\
\hline Wood texture & intact, hard & $\begin{array}{l}\text { intact, hard to partly } \\
\text { decaying }\end{array}$ & $\begin{array}{l}\text { hard, large pieces, } \\
\text { partly decaying }\end{array}$ & $\begin{array}{l}\text { small, blocky } \\
\text { pieces }\end{array}$ & $\begin{array}{l}\text { Many small } \\
\text { pieces, soft } \\
\text { portions }\end{array}$ \\
\hline Portion on ground & $\begin{array}{l}\text { elevated on support } \\
\text { points }\end{array}$ & $\begin{array}{l}\text { elevated but } \\
\text { sagging slightly }\end{array}$ & $\begin{array}{l}\text { sagging near } \\
\text { ground, or broken }\end{array}$ & $\begin{array}{l}\text { all of log on } \\
\text { ground, sinking }\end{array}$ & $\begin{array}{l}\text { all of log on } \\
\text { ground, partly } \\
\text { sunken }\end{array}$ \\
\hline Twigs $<3 \mathrm{~cm}$ & twigs present & no twigs & no twigs & no twigs & no twigs \\
\hline Bark & intact & $\begin{array}{l}\text { intact or partly } \\
\text { missing }\end{array}$ & trace bark & no bark & no bark \\
\hline Shape & round & round & round & round to oval & oval \\
\hline
\end{tabular}

Table 2. Mean values and standard deviation (in brackets) for selected stand characteristics in young (0-70 years), mature (71-140 years) and old ( $>140$ years) sub-boreal and subalpine stands $(n=4$ for sub-boreal, $n=5$ for subalpine except where noted)

\begin{tabular}{|c|c|c|c|c|c|c|}
\hline \multirow[b]{2}{*}{ Stand attributes } & \multicolumn{3}{|c|}{ Sub-boreal } & \multicolumn{3}{|c|}{ Subalpine } \\
\hline & Young & Mature & Old & Young & Mature & Old \\
\hline Tree density (stems/ha) & $644^{1}$ & $\begin{array}{c}811 \\
(175)\end{array}$ & $\begin{array}{c}617 \\
(188)\end{array}$ & $\begin{array}{c}342 \\
(617)^{2}\end{array}$ & $\begin{array}{c}542 \\
(177)\end{array}$ & $\begin{array}{c}558 \\
(311)\end{array}$ \\
\hline Spruce density (stems/ha) & $400^{1}$ & $\begin{array}{c}475 \\
(241)\end{array}$ & $\begin{array}{l}158 \\
(56)\end{array}$ & $1044^{1}$ & $11^{1}$ & $\begin{array}{c}133 \\
(103)\end{array}$ \\
\hline Subalpine fir density (stems/ha) & $244^{1}$ & $\begin{array}{c}333 \\
(136)\end{array}$ & $\begin{array}{c}455 \\
(175)\end{array}$ & $\begin{array}{c}33.3 \\
(15.7)^{2}\end{array}$ & $\begin{array}{c}540 \\
(181)\end{array}$ & $\begin{array}{c}424 \\
(344)\end{array}$ \\
\hline Main canopy density (stems/ha) & $244^{1}$ & $\begin{array}{l}319 \\
(72)\end{array}$ & $\begin{array}{l}128 \\
(58)\end{array}$ & $\begin{array}{c}173 \\
(332)^{2}\end{array}$ & $\begin{array}{c}182 \\
(112)\end{array}$ & $\begin{array}{l}158 \\
(64)\end{array}$ \\
\hline Snags $<15$ cm dbh (stems/ha) & $\begin{array}{c}69 \\
(80)\end{array}$ & $\begin{array}{l}56 \\
(63)\end{array}$ & $\begin{array}{l}25 \\
(29)\end{array}$ & $\begin{array}{c}67 \\
(97)\end{array}$ & $\begin{array}{l}19 \\
(6)\end{array}$ & $\begin{array}{l}36 \\
(23)\end{array}$ \\
\hline Snags $15-25 \mathrm{~cm}$ dbh (stems/ha) & $\begin{array}{l}86 \\
(52)\end{array}$ & $\begin{array}{c}14 \\
(14)\end{array}$ & $\begin{array}{c}17 \\
(11)\end{array}$ & $\begin{array}{c}222 \\
(177)\end{array}$ & $\begin{array}{c}64 \\
(23)\end{array}$ & $\begin{array}{c}52 \\
(23)\end{array}$ \\
\hline Snags $>25$ cm dbh (stems/ha) & $\begin{array}{l}103 \\
(83)\end{array}$ & $\begin{array}{c}25 \\
(32)\end{array}$ & $\begin{array}{l}39 \\
(29)\end{array}$ & $\begin{array}{c}253 \\
(129)\end{array}$ & $\begin{array}{c}158 \\
(150)\end{array}$ & $\begin{array}{c}62 \\
(58)\end{array}$ \\
\hline Snag density (stems/ha) & $\begin{array}{c}258 \\
(138)\end{array}$ & $\begin{array}{c}94 \\
(91)\end{array}$ & $\begin{array}{c}80 \\
(46)\end{array}$ & $\begin{array}{c}440 \\
(428)\end{array}$ & $\begin{array}{c}220 \\
(176)\end{array}$ & $\begin{array}{l}122 \\
(73)\end{array}$ \\
\hline Snag basal area $\left(\mathrm{m}^{2} / \mathrm{ha}\right)$ & $\begin{array}{c}10.6 \\
(16.2)\end{array}$ & $\begin{array}{c}7.4 \\
(9.6)\end{array}$ & $\begin{array}{l}12.3 \\
(1.1)\end{array}$ & $\begin{array}{c}25.8 \\
(19.9)\end{array}$ & $\begin{array}{c}17.7 \\
(14.8)\end{array}$ & $\begin{array}{c}8.0 \\
(6.7)\end{array}$ \\
\hline Mean dbh main canopy $(\mathrm{cm})$ & $24.2^{1}$ & $\begin{array}{l}32.1 \\
(8.2)\end{array}$ & $\begin{array}{l}49.5 \\
(6.3)\end{array}$ & $\begin{array}{l}22.5 \\
(4.1)\end{array}$ & $\begin{array}{c}27.5 \\
(7.9)\end{array}$ & $\begin{array}{c}38.8 \\
(12.6)\end{array}$ \\
\hline Mean dbh spruce $(\mathrm{cm})$ & $15.7^{1}$ & $\begin{array}{l}27.9 \\
(9.3)\end{array}$ & $\begin{array}{l}42.9 \\
(8.9)\end{array}$ & $18.9^{1}$ & $19.7^{1}$ & $\begin{array}{l}41.6 \\
(4.1)\end{array}$ \\
\hline Mean dbh subalpine fir $(\mathrm{cm})$ & $\begin{array}{c}21.7^{1} \\
(7.4)\end{array}$ & $\begin{array}{l}17.0 \\
(3.5)\end{array}$ & $\begin{array}{l}21.6 \\
(4.0)^{2}\end{array}$ & $\begin{array}{l}16.7 \\
(4.6)\end{array}$ & $\begin{array}{c}20.7 \\
(3.3)\end{array}$ & 18.3 \\
\hline CWD volume $<15 \mathrm{~cm}$ diameter $\left(\mathrm{m}^{3} / \mathrm{ha}\right)$ & $\begin{array}{l}16.4 \\
(5.7)\end{array}$ & $\begin{array}{l}13.3 \\
(22.5)\end{array}$ & $\begin{array}{c}9.0 \\
(3.6)\end{array}$ & $\begin{array}{c}9.7 \\
(9.5)\end{array}$ & $\begin{array}{c}4.7 \\
(3.0)\end{array}$ & $\begin{array}{c}8.1 \\
(5.8)\end{array}$ \\
\hline CWD volume $15-25 \mathrm{~cm}$ diameter $\left(\mathrm{m}^{3} / \mathrm{ha}\right)$ & $\begin{array}{c}41.0 \\
(19.6)\end{array}$ & $\begin{array}{c}58.7 \\
(70.6)\end{array}$ & $\begin{array}{l}58.5 \\
(6.9)\end{array}$ & $\begin{array}{c}29.8 \\
(16.3)\end{array}$ & $\begin{array}{c}31.6 \\
(22.6)\end{array}$ & $\begin{array}{c}39.2 \\
(26.0)\end{array}$ \\
\hline CWD volume $>25 \mathrm{~cm}$ diameter $\left(\mathrm{m}^{3} / \mathrm{ha}\right)$ & $\begin{array}{c}132.4 \\
(56.8)\end{array}$ & $\begin{array}{l}175.7 \\
(99.0)\end{array}$ & $\begin{array}{c}183.9 \\
(54.2)\end{array}$ & $\begin{array}{l}72.9 \\
(29.6)\end{array}$ & $\begin{array}{l}117.8 \\
(55.9)\end{array}$ & $\begin{array}{c}157.6 \\
(178.5)\end{array}$ \\
\hline Total CWD volume $\left(\mathrm{m}^{3} / \mathrm{ha}\right)$ & $\begin{array}{l}189.8 \\
(67.5)\end{array}$ & $\begin{array}{l}264.9 \\
(65.9)\end{array}$ & $\begin{array}{l}251.3 \\
(50.1)\end{array}$ & $\begin{array}{l}111.6 \\
(24.2)\end{array}$ & $\begin{array}{l}154.2 \\
(48.6)\end{array}$ & $\begin{array}{c}204.9 \\
(203.6)\end{array}$ \\
\hline
\end{tabular}

${ }_{1}$ only one plot had trees with $>7.5 \mathrm{~cm}$ dbh.

${ }^{2}$ based on four plots, for three of the plots trees over $7.5 \mathrm{~cm}$ dbh were from the pre-disturbance cohort.

subalpine and boreal biogeoclimatic units. Stem density of mature (71-140 years) and old (> 140 years) sub-boreal stands ranged from 410 for the oldest stand sampled (approximately 300 years old) to 966 stems/ha for a 136-year-old mature stand. Stem density of mature and old subalpine stands ranged from 334 stems/ha for a 100-year-old stand at $1350 \mathrm{~m}$ elevation to 1078 stems/ha for a $250+$ year-old stand with fairly dense advanced regeneration of subalpine fir at $1480 \mathrm{~m}$ elevation.

Table 2 shows the mean and standard deviation for density of live trees and snags. Young stands are poorly represent- ed by this data since only one stand had trees above the measurement cutoff of $7.5 \mathrm{~cm}$ dbh. For sub-boreal stands, spruce density was highest in stands $<100$ years old, whereas subalpine fir density peaked in stands $>100$ years old (Fig. 1). The tree layer (> $10 \mathrm{~m}$ in height) of natural stands develops very slowly over time. Even in mature stands, mean cover of the tree layer ( $>10 \mathrm{~m}$ in height) averaged $20 \%$ for sub-boreal and $22 \%$ for subalpine stands compared to crown cover of approximately $70 \%$ predicted by TIPSY for a managed stand of the same age class. 


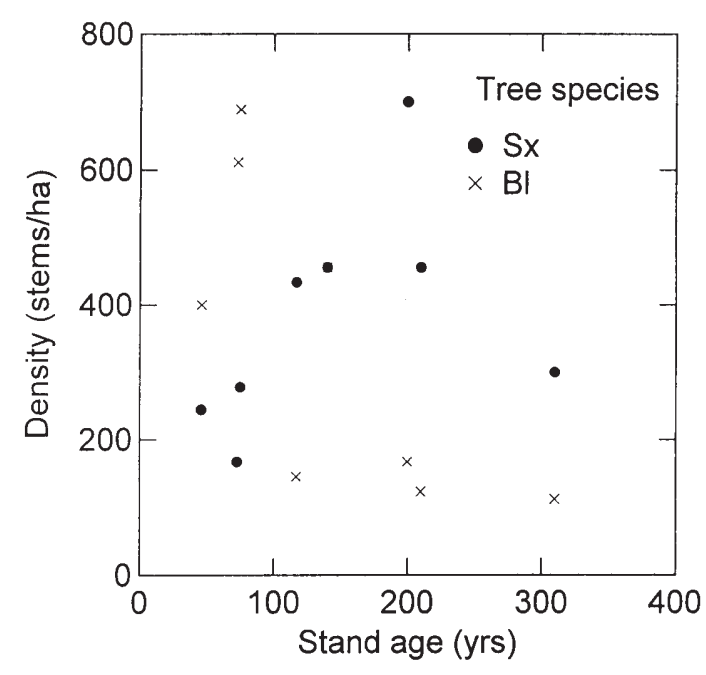

Fig. 1. Density of hybrid white spruce ( $\mathrm{Sx})$ and subalpine fir $(\mathrm{Bl})$ as a function of stand age for the sub-boreal stands.

In sub-boreal stands, there was a strong linear relationship between average diameter of spruce and stand age $(\mathrm{n}=8, \mathrm{p}=$ $\left.0.00, R^{2}=0.82\right)$ but not for subalpine stands $(n=6, p=0.11$, $\mathrm{R}^{2}=0.39$ ). The relationship between average diameter of subalpine fir and stand age was not significant $(p>0.05)$ for either sub-boreal or subalpine stands. Average diameter of the main canopy was consistently lower for subalpine stands compared to sub-boreal stands (Table 2).

All > 50-year-old stands had stems well distributed over a range of diameter classes (Fig. 2). Based on data from all plots in mature sub-boreal stands, spruce was more prominent in the larger diameter classes while subalpine fir was more prominent in the smallest diameter classes (Fig. 3a). Spruce prominence was lower across all diameter classes in old versus mature sub-boreal stands, whereas subalpine fir prominence was similar for both stand age classes (Fig. 3). The negative exponential distribution of subalpine fir prominence value by diameter class mirrors that for subalpine fir density detected in most of the sub-boreal stands (Fig. 2 and 3). No consistent pattern could be detected in the prominence of spruce versus subalpine fir for the sampled subalpine stands.

The proportion of spruce to subalpine fir was higher in sub-boreal stands $(0.40)$ than subalpine stands $(0.26)$. Whereas spruce was present in all sub-boreal stands, it was absent in five of 15 stands in the subalpine. All of the five subalpine stands lacking spruce were above $1300 \mathrm{~m}$. The proportion of spruce to subalpine fir in both the sub-boreal and subalpine stands decreased with relative stand age (Table 1 and Fig. 1).

\section{Stand density comparison}

For the first 100 years post-disturbance, the wet montane sub-boreal and subalpine stands were much less dense than fire-origin sub-boreal stands sampled within a moist subboreal climate (Fig. 4). BCMF records for young managed stands in these two landscapes indicate similar stocking levels, 500-21 000 stems/ha (average 3475 stems/ha) for moist subboreal and 600-13 640 stems/ha (average 2362 stems/ha) for wet montane stands.

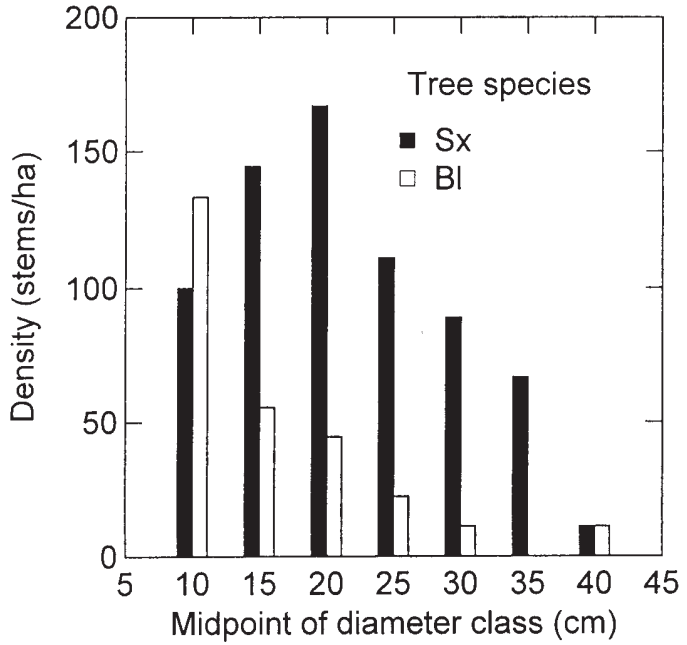

Fig. 2. Density histogram of a mature sub-boreal stand approximately 75 years since disturbance.

Despite the uneven stocking in most stands, a distinct postdisturbance cohort of spruce was present for two of the mature stands in the sub-boreal that burned about 75 years ago. However, compared to that predicted for a modelled managed stand of the same age, the peak in spruce density is less pronounced in these stands (Fig. 5). As well, total stocking of spruce in the natural stands is about half of that expected for a managed stand given current stocking levels (Fig. 5).

\section{Snag attributes}

In sub-boreal stands, density of mid-sized snags $(15-25 \mathrm{~cm}$ dbh) was significantly higher in young stands than mature or old stands $(n=4, p=0.02)$. There were no significant differences in snag density between age classes in the subalpine stands. Snag density within both the sub-boreal and subalpine stands appears to reach a low between 50 and 100 years but it is highly variable (Fig. 6). The density of snags was consistently higher for all stand age classes in subalpine versus sub-boreal stands (Table 2). For the sub-boreal stands, basal area of snags was relatively consistent between stand age classes but much less variable within old stands. In contrast, basal area of snags for the subalpine stands decreased with stand age class (Table 2). Basal area of snags in young and mature stand age classes was higher in the subalpine than the sub-boreal stands (Table 2). The proportion of snags containing birdexcavated cavities was $0.34,0.17$, and 0.40 for sub-boreal and $0.12,0.56$, and 0.22 for subalpine young, mature and old stands, respectively.

\section{Coarse woody debris}

Total coarse woody debris (CWD) volume ranged from a low of $32 \mathrm{~m}^{3} / \mathrm{h}$ for a subalpine stand $(1480 \mathrm{~m},>230$ years old) to a high of $377 \mathrm{~m}^{3} /$ ha for a 140 -year-old sub-boreal stand. There was no apparent relationship between age since disturbance and CWD volume for either subalpine or sub-boreal stands except that the range in values appeared to increase over time (Fig. 7). No significant differences in average total CWD volume or volume by size class were detected between stand age classes for either sub-boreal or subalpine stands. Average 


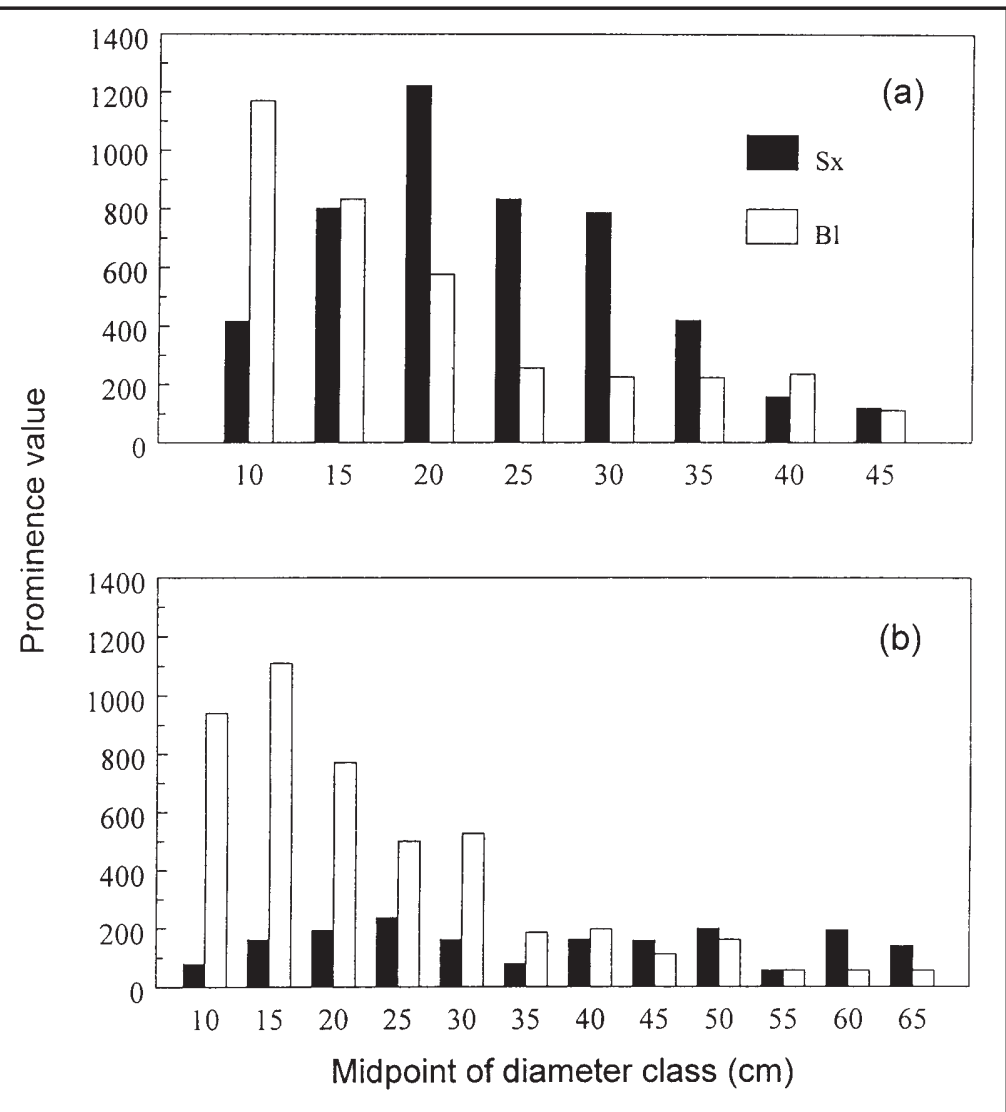

Fig. 3. Prominence value for hybrid white spruce (Sx) and subalpine fir (Bl) by diameter class for a) mature and b) old sub-boreal stands.

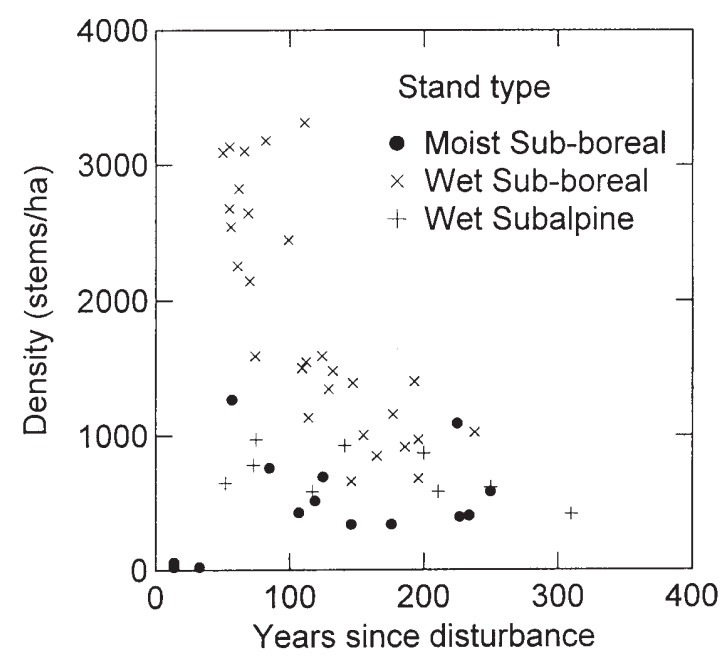

Fig. 4. Stand density over time since disturbance for moist sub-boreal, wet sub-boreal and wet subalpine stands.

CWD volume was consistently higher in sub-boreal than in subalpine stands (Table 2, Fig. 8). CWD volume was heavily apportioned to decay classes 2 to 4 in all stand age classes (Fig. 8). In both sub-boreal and subalpine stands, less than $15 \%$ of the CWD volume was $<17.5 \mathrm{~cm}$ in diameter.

\section{Discussion}

Tree and snag densities of the subalpine stands were lower than those reported by BCMF (2001) for stands > 100 years old

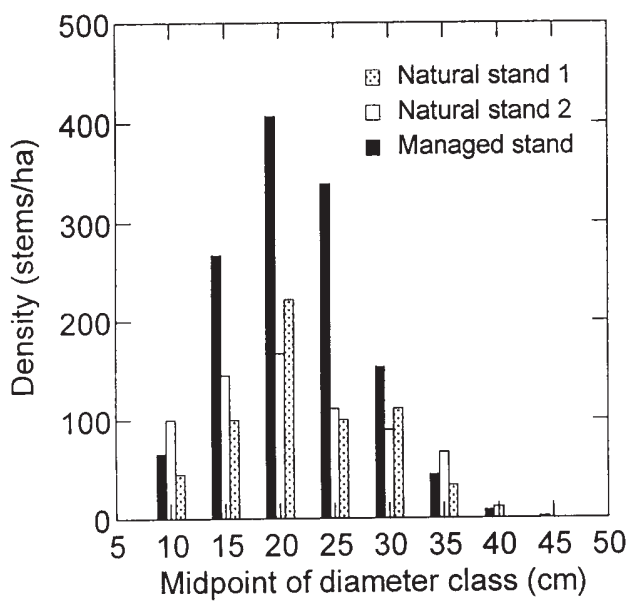

Fig. 5. Comparison of density histograms of spruce for two natural sub-boreal stands and a modelled managed stand 75 years post-disturbance (managed stand specifications for the TIPSY model were 1400 trees/ha planted white spruce with one-year regeneration delay).

in the ESSFwc3 which were 703.1 (SD 506.9) and 184.6 (SD (SD 244.8) stems/ha respectively, for average sites. No published density information was found for the ESSFwk2 or SBSvk. No published CWD information was available for any of the biogeoclimatic units examined.

In subalpine stands, we found the slow establishment rate, open structure, and variability of tree sizes reported for other high-elevation forests dominated by spruce and subalpine fir 


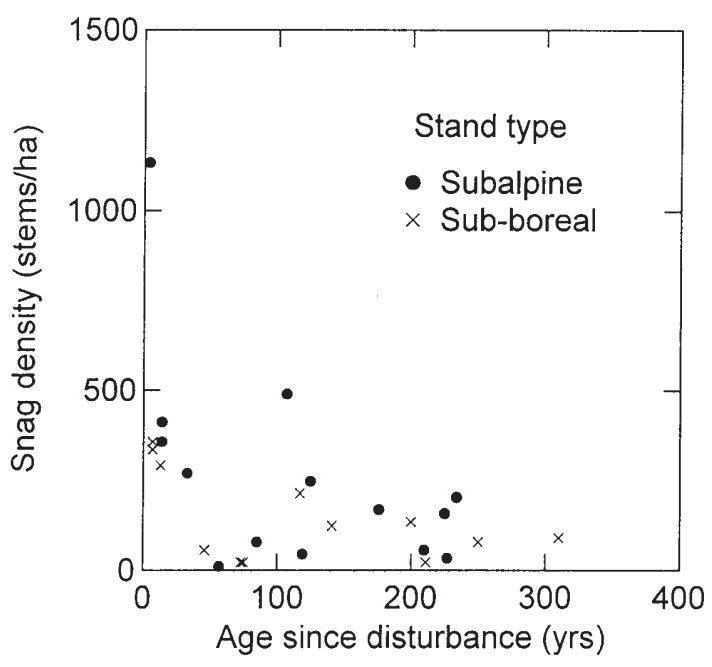

Fig. 6. Density of snags over time since disturbance for sub-boreal and subalpine stands.

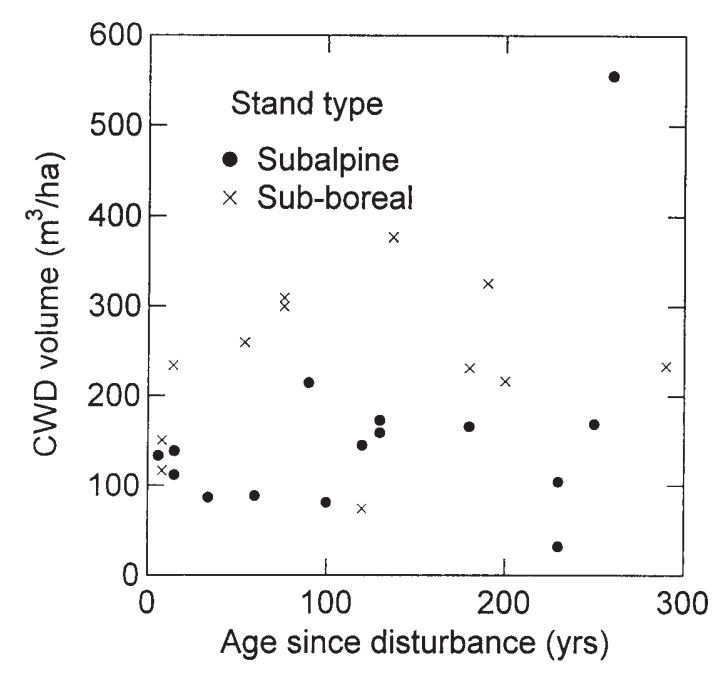

Fig. 7. Volume of CWD over time since disturbance for sub-boreal and subalpine stands.

(Agee and Smith 1984, Parish et al. 1999). However, the observed pattern of stand development of sub-boreal stands is not typical of low-elevation fire-origin stands. Typically, low-elevation stands originating from stand-replacing fires undergo stages of stand initiation, stem exclusion and understory reinitiation over time (Oliver 1981). These developmental stages have been demonstrated in moist sub-boreal forests (Clark 1994) and other forests where spruce and subalpine fir dominate in older stands (Day 1972). We did not detect a stem exclusion stage in the stands examined. The sampled mature wet sub-boreal stands have a lower and less variable tree and snag density compared with the moist sub-boreal stands that typify the stand development described by Oliver (1981). In addition, for mature stands in our sample, the low proportion $(<10 \%)$ of CWD with diameters of $7.5-17.5 \mathrm{~cm}$ indicates a lack of mortality relat-

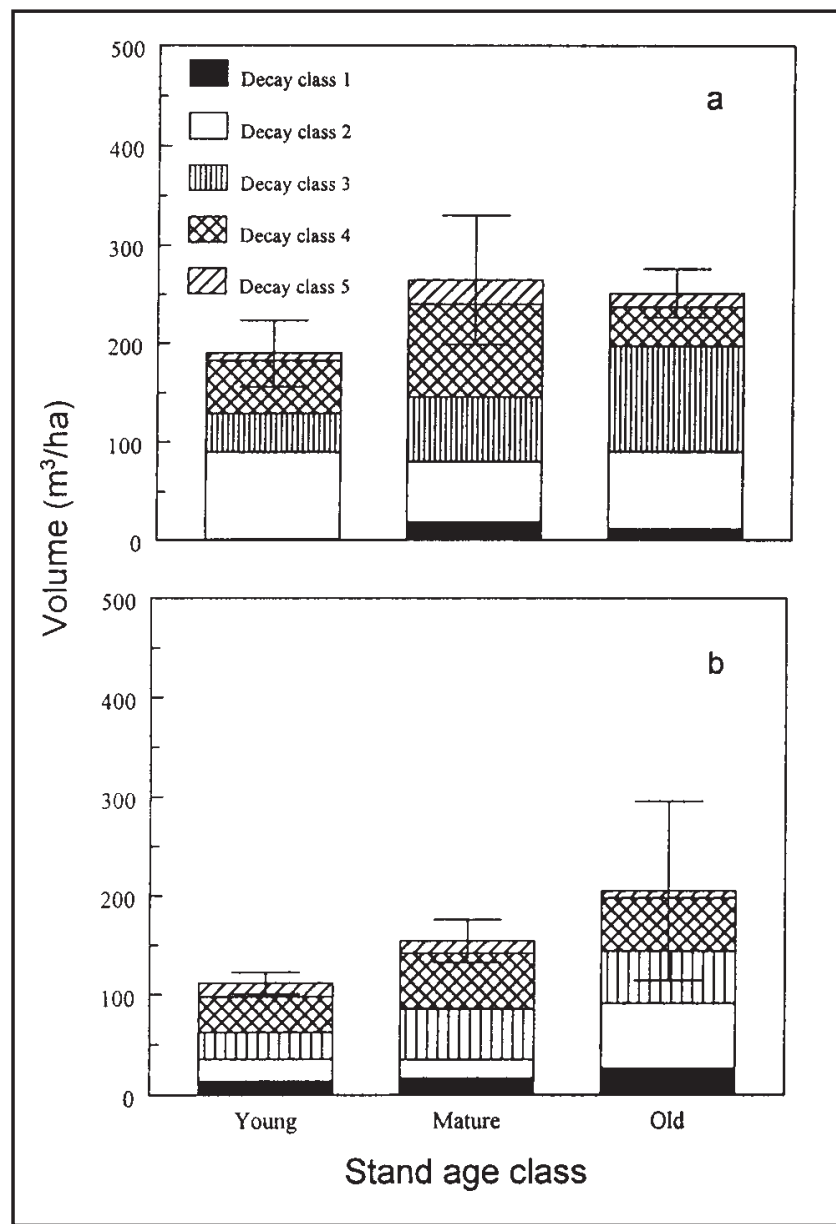

Fig. 8. Volume of CWD in different decay classes in young, mature and old age classes for a) sub-boreal stands and b) subalpine stands.

ed to self-thinning. In contrast, in mature (71-140 years) moist sub-boreal stands, $40 \%$ of the CWD were $7.5-17.5 \mathrm{~cm}$ in diameter (DeLong and Kessler 2000).

Sub-boreal stands of all ages, within the sampling area, demonstrate stand attributes common to older forest stands such as a wide variation in tree size, an open main canopy, and an inverse “j”-shaped distribution of subalpine fir stems. Apart from a higher proportion of subalpine fir and a general increase in diameter of the main canopy over time, differences in stand structure relating to stand age was limited. Factors relating to the very wet cool climate of the area may help explain the observed development of stand structure of these wet montane sub-boreal stands. The long fire cycle within the SBSvk, estimated by Hawkes et al. (1997) to exceed 500 years, limits lodgepole pine, a widespread fire-dependent species in most sub-boreal and boreal forests, to very dry sites and wetlands (DeLong 1996). Lodgepole pine generally establishes at high densities and leads to the stem exclusion stage in other sub-boreal stands (Clark 1994). Also uncommon are western hemlock and western red cedar (Thuja plicata Donn ex D. Don in Lamb.) which regenerate at high density following fire on average sites in wet but warmer climates (unpublished data, DeLong). The climate of the area also leads to well-developed shrub and herb layers that aggressively compete for resources (Brand 1991, DeLong 1991), which would slow the establishment of conifer seedlings. 
Under current stocking guidelines (e.g., 1400 stems/ha), managed stands are likely to have lower sub-canopy light levels than the natural stands as a consequence of higher crown closure. This could reduce understory vegetation development (Alaback 1982, Messier et al. 1998) and lead to more poorly developed vertical stand structure (Messier et al. 1999) in managed stands. This could have important implications for species such as grizzly bears (Ursus arctos L.), which utilize shrub or herb dominated gaps within forested areas (unpublished data, J. Paczkowski, Prince George, B. C.). Increasing stocking and decreasing the number of gaps could also have implications for long-term stand nutrition. Kimmins and Hawkes (1978) examined stands on coarse-textured nutrient-poor soils within our study area and found that most of the nutrients were held in the rich humus layer. They hypothesized that the abundant understory vegetation, which is both a cause and effect of open stand structure, contributed to nutrient conservation and rapid turnover of nutrients enabling the maintenance of productive stands on the nutrient-poor soils.

The lower proportion of spruce to subalpine fir in subalpine versus sub-boreal stands is not reflected in current plantation management practices. For instance, in the past year, about $90 \%$ of the stock planted above $950 \mathrm{~m}$ within the general area of the study consisted of Engelmann spruce (unpublished data, BCMF). Although natural ingress of subalpine fir is expected these managed stands will still have a higher component of Engelmann spruce than natural stands. The effect of a potential species shift, while uncertain, may have implications for stem rot organism, insect, and bird interactions. Stem rot tends to occur at a younger age in subalpine fir versus spruce, thus inducing early development of soft wood favoured by wood boring insects and the birds that feed on them. This could be especially important above $1300 \mathrm{~m}$ where the species shift from natural to managed stands would be dramatic.

The lower number of snags 50-100 years post-disturbance could reflect fall down of snags from the pre-disturbance stand without significant recruitment from the post-disturbance stand. The pre-disturbance origin snags may be important to wildlife as suggested by the high proportion of trees showing evidence of feeding cavities in the young sub-boreal stands. Hutto (1995), in a study of bird communities following stand-replacement fires in the Rocky Mountains of Montana, found that black-backed woodpeckers (Picoides arcticus Swainson) were generally restricted in their habitat distribution to standing dead forests created by stand-replacement fires. This brings into question the common practice of harvesting fire-killed stands.

Volume of CWD for the sub-boreal stands examined was 1.5 to 3 times higher, for all age classes, than reported for sub-boreal stands in drier climates in west-central British Columbia (Clark et al. 1998). Volume of CWD in both the sub-boreal and subalpine stands appear unrelated to stand age. Harmon et al. (1986) proposed a simple model describing the changes in CWD biomass during stand development. An initial pulse of pre-disturbance origin CWD input is followed by a decline in CWD as debris generation drops. Finally, CWD input increases due to mortality of larger stems in older stands. This "U"-shaped distribution has been documented for forests of the Pacific Northwest and moist sub-boreal forests of British Columbia (Agee and Huff 1987, Spies et al. 1988, Clark et al. 1998). For the wet montane stands examined, we hypothesize that a fairly constant supply of large stems combined with slow decomposition rates leads to a relatively constant volume of CWD on the ground. At least $25 \%$ of snags were $>25 \mathrm{~cm}$ in diameter. Average diameter of stems was about double that reported for the same age class of moist sub-boreal stands (DeLong and Kessler 2000).

The results of this study indicate that stand structural features peculiar to the wet montane forests should be considered by forest managers when developing stand level prescriptions. Current stand management practices in the study area appear to emulate natural stand development of moist sub-boreal forests but diverge significantly from the wet montane forests. Current forest management appears to be successful at establishing relatively dense stands in the wet sub-boreal. A report by Deschamps (1998) found that density increased over time since clearcutting up to the oldest age class sampled. These 21-30year-old stands had an average density of $2170 \mathrm{stems} / \mathrm{ha}>1.3 \mathrm{~m}$ in height. The majority of these stems should persist as they are above the competing shrub/herb community. Planting trees in groups at lower densities, and thinning in some stands would assist with reducing the apparent divergence in stand density between natural and managed stands. The development of stand structure of managed stands that diverge greatly from natural stands needs to be closely examined to determine potential ecological impacts. The Blue Mountains in Oregon, where dramatic increases in Douglas-fir density following fire suppression appear related to extensive forest health problems, illustrate the potential impact of altering natural stand development (Hessburg et al. 1994). Our study emphasizes the importance of developing climate-specific stand management guidelines rather than adopting generalized guidelines for climatically diverse areas.

\section{Acknowledgements}

The research in the paper was collected as part of the Ecological Processes Research Program funded by the McGregor Model Forest Association, one of eleven model forests in the Model Forest Network established by the Government of Canada. We would like to thank Wayne Blashill, Kevin Driscoll, Wendy Vasbinder, Brad Hawkes, and Arlene McEwen for assistance with fieldwork. Thanks also go to Dr. André Arsenault and Dr. Winifred Kessler for reviewing earlier drafts of the paper.

\section{References}

Agee, J.K. and M.H. Huff. 1987. Fuel succession in a western hemlock/Douglas-fir forest. Can. J. For. Res. 24: 697-704.

Agee, J.K. and L. Smith. 1984. Subalpine tree reestablishment after fire in the Olympic Mountains, Washington. Ecology 65: 810-819. Alaback, P.B. 1982. Dynamics of understory biomass in Sitka spruce-western hemlock forests of southeast Alaska. Ecology 63: 1932-1948

Amaranthus, M., J.M. Trappe, L. Badnar and D. Archer. 1994. Hypogeous fungal production in mature Douglas-fir forest fragments, and surrounding plantations and its relation to coarse woody debris and animal mycophagy. Can. J. For. Res. 24: 2157-2165.

Andison, D. 1996. Managing for landscape patterns in the sub-boreal forests of British Columbia. Ph.D. Thesis, University of British Columbia, Vancouver. 197 p.

Bader, P., S. Jansson and B.G. Jonsson. 1995. Wood-inhabiting fungi and substratum decline in selectively logged boreal spruce forests. Biol. Cons. 72: 355-362.

Bergeron, Y. and B. Harvey. 1997. Basing silviculture on natural ecosystem dynamics: an approach applied to the southern boreal mixedwood forest of Quebec. For. Ecol. Manage. 92: 235-242. 
Brand, D.G. 1991. The establishment of boreal and sub-boreal conifer plantations: an integrated analysis of environmental conditions and seedling growth. For. Sci. 37: 68-100.

British Columbia Ministry of Forests (BCMF). 1992. Forest inventory manual. Queens Printer, Victoria, B.C. 132 p.

British Columbia Ministry of Forests (BCMF). 2001. Mensuration data from the provincial ecology program. For. Sci. Prog., B.C. Min. For., Victoria, B.C. Working Paper 62. 421 p.

Bunnell, F.L. 1995. Forest-dwelling vertebrate faunas and natural fire regimes in British Columbia. Cons. Biol. 9: 636-644.

Carey, A. B., J. Kershner, B. Biswell and L. Dominguez de Toledo. 1999. Ecological scale and forest development: squirrels, dietary fungi, and vascular plants in managed and unmanaged forests. Wildl. Mono. 142: 1-71.

Clark, D.F. 1994. Post-fire succession in the sub-boreal spruce forests of the Nechako Plateau, central British Columbia. M. Sc. Thesis. University of Victoria, Victoria. $124 \mathrm{p}$.

Clark, D.F., D.D. Kneeshaw, P.J. Burton and J.A. Antos. 1998. Coarse woody debris in sub-boreal spruce forests of west-central British Columbia. Can. J. For. Res. 28: 284-290.

Day, R.G. 1972. Stand structure, succession, and use of southern Alberta's Rocky Mountain forest. Ecology 53: 472-478.

DeLong, S.C. 1991. The light interception index: a potential tool for assisting in vegetation management decisions. Can. J. For. Res. 21: $1037-1042$.

DeLong, S.C. 1996. A field guide for site identification and interpretation for the southeast portion of the Prince George Forest Region. B.C. Min. For. author's draft. Prince George, B.C. 193 p. DeLong, S.C. 1998. Natural disturbance rate and patch size distribution of forests in northern British Columbia: Implications for forest management. Northwest Sci. 72: 35-48.

DeLong, C., D. Tanner and M.J. Jull. 1993. A field guide for site identification and interpretation for the southwest portion of the Prince George Forest Region. B.C. Min. For., Victoria, B.C. Land Management Handbook No. 20. 290 p.

DeLong, C., D. Tanner and M.J. Jull. 1994. A field guide for site identification and interpretation for the northern Rockies portion of the Prince George Forest Region. B.C. Min. For., Victoria, B.C. Land Management Handbook No. 29. 141 p.

DeLong, S.C. and D. Tanner. 1996. Managing the pattern of forest harvest: lessons from wildfire. Biod. Cons. 5: 1191-1205.

DeLong, S.C. and W.B. Kessler. 2000. Ecological characteristics of mature forest remnants left by wildfire. For. Ecol. Manage. 131: 93-106. Deschamps, K. 1998. Retrospective studies of clearcutting and silviculture techniques in the McGregor Model Forest. Final report for McGregor Model Forest Association, Prince George, British Columbia, Canada. (available on web at http://www.mcgregor.bc.ca/). Dupuis, L.A., J.N.M. Smith and F. Bunnell. 1995. Relation of terrestrial-breeding amphibian abundance to tree-stand age. Cons. Biol. 9: 645-653.

Franklin, J.F. 1989. Towards a new forestry. Am. For. November/December: 37-44.

Hansen, A.J., T.A. Spies, F.J. Swanson and J.F. Ohmann. 1991. Conserving biodiversity in managed forests: lessons from natural forests. Bioscience 41: 382-392.

Harmon, M.E., J.F. Franklin, F.J. Swanson, P. Sollins, S.V. Gergory, J.D. Lattin, N.H. Anderson, S.P. Cline, N.G. Aumen, J.R. Sedell, Jr.K. Cromack and K.W. Cummins. 1986. Ecology of coarse woody debris in temperate ecosystems. Adv. Ecol. Res. 15: 133-302.

Harmon, M.E. and J.F. Franklin. 1989. Tree seedlings on logs in Picea-Tsuga forests of Oregon and Washington. Ecology 70: 48-59. Hawkes, B., W. Vasbinder and C. DeLong. 1997. Retrospective fire study: Fire regimes in the SBSvk and ESSFwk2/wc3 biogeoclimatic units of northeastern British Columbia. Final report for McGregor Model Forest Association, Prince George, British Columbia, Canada. (available on web at http://www.mcgregor.bc.ca/).
Hessburg, P.F., R.G. Mitchell and G.M. Filip. 1994. Historical and current roles of insects and pathogens in eastern Oregon and Washington forested landscapes. USDA Forest Service General Technical Report PNW-GTR-327. Portland, OR, USA. 72 p.

Hunter, M.L., Jr. 1993. Natural fire regimes as spatial models for managing boreal forests. Biological Conservation 65: 115-20.

Hutto, R.L. 1995. Composition of bird communities following stand-replacement fires in Northern Rocky Mountain (U.S.A.) conifer forests. Cons. Biol. 9: 1041-1058.

Kaila, L., P. Martikaninen and P. Punttila. 1997. Dead trees left in clear-cuts benefit saproxylic Coleoptera adapted to natural disturbances in boreal forest. Biod. Cons. 6: 1-18.

Kimmins, J.P. and B.C. Hawkes. 1978. Distribution and chemistry of fine roots in a white spruce-subalpine fir stand in British Columbia: implications for management. Can. J. For. Res. 8: 265-279.

Kneeshaw, D.D. 1992. Tree population dynamics of some oldgrowth sub-boreal spruce stands. M. Sc. Thesis, University of British Columbia. 152 p.

Lesica P., B. McCune, S.V. Cooper and W.S. Hong. 1991. Differences in lichen and bryophyte communities between old-growth and managed second-growth forests of Swan Valley, Montana. Can. J. Bot. 69: 1745-1755.

Mannan, R.W., E.C. Meslow and H.M. Wight. 1980. Use of snags by birds in Douglas-fir forests, western Oregon. J. Wild. Manage. 44: 787-797.

Messier, C., R. Parent and Y. Bergeron. 1998. Characterization of understory light in closed boreal forests: effects of overstory and understory vegetation. J. Veg. Sci. 9: 511-520.

Messier, C., R. Doucet, J-C. Ruel, Y. Claveau, C. Kelly and M.J. Lechowicz. 1999. Functional ecology of advance regeneration in relation to light in boreal forests. Can. J. For. Res. 29: 812-823. Mitchell, K.J. 1975. Dynamics and simulated yield of Douglas-fir. For. Sci. Mono. 17: 1-39.

Mueller-Dombois D. and H. Ellenberg. 1974. Aims and methods of vegetation ecology. John Wiley and Sons, Toronto, Ont. 547 p. Neitro, W.A., R.W. Mannan, D. Taylor, V.W. Binkley, B.G. Marcot, F.F. Wagner and S.P. Cline. 1985. Snags (Wildlife trees). In E.R. Brown (tech. ed.). Management of Wildlife and Fish Habitats in Forests of Western Oregon and Washington. pp. 129-170. USDA Forest Service, Pacific Northwest Forest Service, Portland, Oregon. Oliver, C.D. 1981. Forest development in North America following major disturbances. For. Ecol. Manage. 3: 153-168.

Parish, R., J.A. Antos and M-J. Fortin. 1999. Stand development in an old-growth subalpine forest in southern interior British Columbia. . Can. J. For. Res. 29: 1347-1356.

Sokal, R.R. and F.J. Rohlf. 1969. Biometry. W.H. Freeman and Co. New York. 887 p.

Spies, T.A., J.F. Franklin and T.B. Thomas. 1988. Coarse woody debris in Douglas-fir forests of western Oregon and Washington. Ecology 69: 1689-1702.

Swanson, F.J., J.A. Jones, D.O. Wallin and J.H. Cissel. 1993. Natural variability - Implications for Ecosystem Management. In M.E Jensen and P.S. Bourgeron (eds.). Eastside forest ecosystem health assessment. Volume 2: Ecosystem management: principles and applications. pp. 89-104. U.S. Forest Service, Portland, Oregon.

Thomas, J.W., R.G. Anderson, C. Maser and E.L. Bull. 1979. Snags In J.W. Thomas (tech. ed.). Wildlife habitat in managed forests, the Blue Mountains of Oregon and Washington. pp. 60-77. U.S.DA. Forest Service Handbook. No. 553. U.S. Forest Service, Portland, Oregon.

Trowbridge, R., B. Hawkes, A. Macadam and J. Parminter. 1989. Field handbook for prescribed fire assessments in British Columbia: logging slash fuels. FRDA Handbook 001. B. C. Ministry of Forests, Victoria, B.C. 63 p.

Van Wagner, C.E. 1968. The line intersect method in forest fuel sampling. For. Sci. 14: 20-26.

Van Wagner, C.E. 1978. Age-class distribution and the forest fire cycle. Can. J. For. Res. 8: 220-227. 
Van Wagner, C.E. 1982. Practical aspects of the line intersect method. Petawawa National Forestry Institute Information Report PIX-12. Canadian Forestry Service, Chalk River, Ontario. 11 p.

Wilkinson, L., G. Blank and C. Gruber. 1996. Desktop data analysis with SYSTAT. Prentice Hall, New Jersey. 798 p.
Willson, M.F. 1974. Avian community organization and habitat structure. Ecology 55: 1017-1029.

Zackrisson, O. 1977. Influence of forest fires on the North Swedish boreal forest. Oikos 2: 22-32. 